\title{
HUBUNGAN POLA ASUH PERMISIF DAN IKLIM SEKOLAH DENGAN PERILAKU BULLYING PADA SISWA MTs AL-HALIM SIPOGU \\ Oleh \\ Meutiasari,S.Pd M.Psi \\ Email. Meutiasarihasibuan@gmail.com
}

\begin{abstract}
This study aims to determine the relationship between permissive parenting and school climate with bullying behavior on students of MTs Al-Halim Sipogu. Subjects who become respondents in this study amounted to 40 people.

Data were collected through a scale designed in this study and distributed to the subject of research.

The data were then analyzed by using simple and multiple corelation techniques with the help of SPSS 17 for windows. The result of the analysis shows that there is a positive correlation between permissive parenting pattern and school climate with bullying behavior on students of MTs AlHalim Sipogu.

The value of determination coefficient is 0,639 or have correlation equal to $41,6 \%$. The relationship between permissive parenting variables with bullying behavior is 0.393 or has a relationship of $15.5 \%$ and the coefficient determinasai school climate with bullying behavior of 0.501 or has a relationship of $40.9 \%$.

The conclusion of this research is that there is negative correlation between permissive parenting pattern and school climate with bullying behavior on students of MTs Al-Halim Sipogu with $41,6 \%$.
\end{abstract}

Keywords: Permissive parenting pattern, school climate, bullying behavior.

\section{A. PENDAHULUAN}

Perilaku bullying adalah sebuah situasi dimana terjadinya penyalagunaan kekuatan/kekuasaan yang dilakukakan oleh seseorang/kelompok. Pihak yang kuattidak hanya berarti kuat dalam ukuran fisik, tetapi bisa juga kuat secara mental.

Saling ejek biasanya digunakan sebagai bahan gurauan di kalangan pelajar bahkan dilingkungan sosialpun candaan seperti itu banyak dijumpai. Becanda untuk melepas lelah merupakan hal yang wajar, namun dalam tingkat kewajaran terdapat ukuran tertentu. Becanda yang berlebihan dapat membuat individu merasa tersinggung bahkan terhina sehingga dampakdampak yang tidak diinginkanpun terjadi seperti perilaku bullying.

Perilaku bullying bisa ditumbuhkan oleh candaan yang melampaui batas ataupun faktorfaktor lainnya. Perilaku bullying membuat orang merasa ketakutan ataupun tidak aman dalam menjalani hidup. Jika dikaitan dengan HAM (Hak asasi manusia) perilaku bullying dikategorikan melanggar. Hal ini dikarenakan dalam bullying, pelaku tidak memikirkan hak-hak bahkan keselamatan korban, malah pelaku menyiksa dan melakukan penindasa yang seharusnya tidak boleh dilakukan.

\footnotetext{
${ }^{1}$ Sejiwa, Kekerasan terhadap anak makin memiriskan, Mei, 5, 2016. http://sejiwa.org/kekerasan-terhadap-anak-makin memiriskan/, 2008.
} 
Peristiwa penindasan di lingkungan sekolah (school bullying) yaitu perilaku agresif yang dilakukan berulang-ulang oleh seorang atau sekelompok santri yang berkuasa terhadap santrisantri yang lemah, dengan tujuan menyakiti orang tersebut.

Perilaku bullying adalah kekerasan fisik dan psikologis berjangka panjang yang dilakukan seseorang atau kelompok terhadap seseorang yang tidak mampu mempertahankan diri dalam situasi ada hasrat untuk melukai atau menakuti orang atau membuat orang tertekan, trauma/depresi dan tidak berdaya.

Perilaku bullying sudah lama terjadi di negara Indonesia. Berdasarkan penelitian yang dilakukan oleh Fakultas Psikologi UI. Yayasan Sejiwa dan LSM Plan Indonesia pada tahun 2008 yang menunjukkan bahwa kekerasan antar siswa di tingkat SMA terbanyak terjadi di Jakarta $(72,7 \%)$ kemudian diikuti Surabaya $(67,2 \%)$ dan terakhir yogyakarta $(63,8 \%)$.

Dari data tersebut dapat diketahui bahwa di Indonesia perilaku bullying masih menjadi masalah yang ada di sekolah terutama tingkat sekolah menengah atas.

Ada beberapa bentuk perilaku bullying yang terjadi dalam lingkungan sekolah di MTs AlHalim Sipogu yaitu perilaku bullying dalam bentuk fisik contohnya memukul, mendorong, meninju, menghancurkan barang orang lain, mengancam secara fisik, memelototi, dan mencuri barang.

Perilaku bullying dalam bentuk psikologis seperti, mengucilkan, menyebarkan gosip, mengancam, gurauan yang mengolok-ngolok, secara sengaja mengisolasi seseorang, menghancurkan reputasi seseorang dan mengasingkan seseorang secara social. Juga perilaku bullying dalam bentuk verbal, seperti menghina, membentak, menggunakan kata-kata kasar, menyindir, meneriaki dengan kasar, memanggil dengan julukan, keluarga, ketidakmampuan.

Perilaku bullying dalam bentuk sosial seperti mengucilkan, dan mengabaikan orang. Zaman modern sekarang ini tindakan bullying juga bisa melalui gadget, dan media sosial yang disebut Cyberbullying. Cyberbullying adalah saat seseorang dihina-hina, diteror di media sosial, atau melalui SMS, email, dan telepon.

Salah satu faktor yang mempengaruhi perilaku bullying adalah faktor keluarga, pola asuh keluarga dan orang tua yang menerapkan pola asuh permisif dan otoriter.

Faktor yang mempengaruhi perilaku bullying di sekolah adalah iklim sekolah, kebijakan sekolah dan pengawasan siswa memberikan kontribusi terhadap frekuensi terjadinya masalah perilaku bullying di sekolah di setiap sekolah tertentu.

\footnotetext{
${ }^{2}$ Ahmad Baliyo Eko Prasetyo, Bullying disekolah dan dampaknya bagi masa depan anak, Jurnal Pendidikan Islam : Vol.4. No, 2011.

${ }^{3}$ Abu Darwis, Pengubahan Perilaku Menyimpang Murid Disekolah Dasar, Jakarta : Depdiknas, 2006.

${ }^{4}$ Sejiwa foundation, Penelitian mengenai kekerasan di sekolah, Jakarta:Grasindo, 2010.

${ }^{5}$ Coloroso, The Bully, Bulled and The Bystander. New York, 2006.
} 
Secara konseptual iklim lingkungan atau suasana di sekolah adalah seperangkat atribut yang memberi warna atau karakter, spirit, etos, suasana batin disetiap sekolah, secara operasional sebagaimana halnya defenisi iklim sekolah dapat dilihat dari faktor seperti kurikulum, sarana, dan kepemimpinan kepala sekolah dan lingkungan pembelajaran di kelas.

Iklim sekolah merupakan suatu norma, harapan dan kepercayaan diri dari personil-personil yang terlibat dalam organisasi sekolah yang dapat memberikan dorongan untuk mendukung sebuah kebiasaan atau perilaku yang baik bagi siswanya.

Iklim sekolah adalah suasana dalam organisasi sekolah yang diciptakan oleh pola hubungan antar pribadi yang berlaku. Pola hubungan antar pribadi tersebut dapat meliputi hubungan antara guru dengan murid, antara murid dengan murid antara guru dengan guru dan antara guru dengan pimpinan sekolah.

Berdasarkan hasil wawancara pada tanggal 1-2 januari tahun 2017 dengan guru BK di MTs Al-Halim Sipogu didapatkan data adanya perilaku bullying pada siswa kelas VIII dan kelas VII, yangmelakukan perilaku bullying dalam bentuk verbal yaitu memanggil dengan julukan seperti "Si hitam”, "Si jantan”, "si banci”dan mengejek teman-temannya.

Kemudian hasil observasi pada tanggal 4-5 januari tahun 2017 dengan guru yang sedang mengajar di dalam kelas VII terlihat jelas siswa melakukan perilaku bullying yang berbentuk sosial seperti, mengucilkan teman dengan cara "Siswa tidak mau duduk satu meja dengan korban bullying, tidak mau berteman dengan korban bullying dan sering mengabaikan guru yang sedang menjelaskan materi pelajaran di dalam kelas.

Selain itu berdasarkan hasil observasi pada tanggal 6-7 Januari tahun 2017 dilingkungan sekolah seperti kelas, kantin, masjid. diperoleh data dari siswa bahwa ada seorang siswa Kelas VIII yang bernama "MS", dan "MR" yang menunjukkan perilaku bullying dalam bentuk fisik, contohnya memukul, mendorong, meninju, mengancam secara fisik, memelototi, untuk sesuatu hal yang di inginkannya, yang dilakukan kepada teman sekelasnya dan kelas VII.

Perilaku bullying tidak hanya terjadi untuk siswa laki-laki melainkan bagi siswa perempuan, hal ini terlihat dengan adanya perilaku bullying oleh siswa perempuan di kelas VIII yang bernama "AM" dalam bentuk psikologis seperti, mengucilkan, menyebarkan gosip, mengancam, gurauan yang mengolok-ngolok.

Salah satu contoh perilaku bullying yang terjadi pada tanggal 20 Januari 2017 adalah siswa pelaku bullying suka menyebarkan gosip yang tidak baik kepada teman yang lain, menjelekjelekkan siswa lain kepada guru, penjaga kantin, hal ini dilakukan untuk kepentingannya sendiri demi menginginkan sesuatu yang ingin dicapainya.

\footnotetext{
${ }^{6}$ Olweus, D, Bullying : Fact and intervention. Norwegia: Research Center for Health Promotion, University Of Bergen, 2006.

${ }^{7}$ Dariyo, A \& Ling, Y, Interaksi Sosial Di Sekolah dan iklim sekolah menengah umum (SMU). Phronesis, 2002.
} 
Berdasarkan hasil wawancara pada tanggal 28Januari tahun 2016 Hal ini juga di tegaskan oleh para guru yang ada di MTs Al-Halim sipogu bahwa perilaku bullying sangat mengganggu di lingkungan sekolah yang sering mengakibatkan perkelahian diantara siswa hal ini juga sering melibatkan orang tua untuk ikut serta dalam penyelesaian masalah bullying.

Hal ini terlihat melalui hasil wawancara pada siswa di MTs Al-Halim Sipogu tanggal 1 Pebruari tahun 2017 ditemukan bahwa anak disuruh untuk bekerja dan membiarkan anak tidak sekolah, seperti "menggore"/mencari emas di sungai, orangtua tidak pernah mengatur jam belajar anak, tidak pernah menanyakan PR anak dan jam bermain anak, orang tua tidak pernah memarahi anak meskipun anak melakukan kesalahan, orang tua tidak pernah melarang anak bepergian, orang tua tidak pernah mengajak anak berfikir dahulu sebelum melakukan sesuatu, orang tua tidak pernah memberikan pujian atau hadiah terhadap kesuksesan belajar anak.

Dampak dari pola asuh permisif adalah anak cederung bertindak sesuka hati, bebas dan memiliki perilaku yang tidak terkontrol.

Siswa yang diidentifikasi sebagai pelaku bullying menunjukan 1,65 kali lebih tampak pada anak yang berasal dari keluarga dengan pola asuh otoriter.

Dalam penelitian ini membahas pola asuh permisif, dimana orang tua mengutamakan pemberian respon namun mengabaikan tuntutan. Pola asuh permisif dapat diartikan sebagai pola perilaku orang tua dalam berinteraksi dengan anak, yang membebaskan anak untuk melakukan apa yang ingin dilakukan tanpa mempertanyakan. Pola asuh ini tidak menggunakan aturan-aturan yang ketat bahkan bimbingan pun kurang diberikan, sehingga tidak ada pengendalian atau pengontrolan serta tuntutan kepada anak. Kebebasan diberikan penuh dan anak diijinkan untuk memberi keputusan untuk dirinya sendiri, tanpa pertimbangan orang tua dan berperilaku menurut apa yang diinginkannya tanpa ada kontrol dari orang tua.

\section{B. Tujuan Penelitian}

Adapun tujuan yang ingin dicapai dalam penelitian ini adalah :

1. Adanya hubungan antara pola asuh permisif dengan perilaku bullying pada siswa MTs AlHalim Sipogu.

2. Adanya hubungan antara iklim sekolah dengan perilaku bullying pada siswa MTs Al-Halim Sipogu.

3. Adanya hubungan pola asuh permisif dan iklim sekolah dengan perilaku bullying pada siswa MTs Al-Halim Sipogu. 


\section{KERANGKA TEORI}

\section{PENGERTIAN PERILAKU BULLYING}

Istilah bullying dalam bahasa indonesia belum dirumuskan dan dalam bahasa inggris bullying berasal dari kata bully yang berarti menggertak atau mengganggu orang yang lemah, secara konsep, bullying dapat diartikan sebagai bentuk agresi dimana terjadi ketidak seimbangan kekuatan atau kekuasaan antar pelaku (bullies/bully) dengan korban (victim).

Perilaku bullying adalah bentuk keinginan untuk menyakiti dan sebagian besar harus melibatkan ketidak seimbangan kekuatan serta orang atau kelompok yang menjadi korban adalah yang tidak memiliki kekuatan dan perlakuan ini terjadi berulang-ulang dan diserang secara tidak adil.

Bullying berasal dari bahasa Inggris (bully) yang berarti menggertak atau mengganggu. Ada banyak definisi mengenai perilaku bullying, terutama yang terjadi dalam konteks lain (tempat kerja, masyarakat, komunitas, organisasi). Namun, disini peneliti akan membatasi konteksnya dalam school bullying (kekerasan di sekolah).

School bullying (Kekerasan di sekolah) adalah perilaku agresif yang dilakukan berulangulang oleh seorang/sekelompok santri yang memiliki kekuasaan, terhadap santri-santri lain, dengan tujuan menyakiti santri tersebut.

Kekerasan yang terjadi di sekolah atau biasa disebut dengan perilaku bullying tidaklah sama dengan kenakalan anak-anak pada umumnya. perilaku bullying merupakan perkataan maupun sikap agresif yang dilakukan secara berulang-ulang. Mereka menyakiti secara fisik maupun mental dengan tujuan menyakiti korban.

Perilaku bullying dapat berupa tindakan fisik, verbal, emosional, maupun seksual. Berdasarkan definisi di atas, perilaku bullying yang dilakukan tidak semua tergolong bullying fisik. Justru kebanyakan perilaku bullying dengan kata-kata, baik berupa penyebaran gosip maupun pemberian julukan-julukan tertentu yang bertujuan mengejek.

Dari uraian di atas dapat disimpulkan bahwa perilaku bullying merupakan niat yang dimiliki individu atau sekelompok orang untuk menyakiti, membuat orang lain merasa kesusahan. yang muncul dari kekuatan fisik, usia, status sosial, status ekonomi keluarga, popularitas atau bahkan karena kecakapan intelektual. Terhadap seseorang yang tidak mampu mempertahankan diri dalam situasi dimana ada hasrat untuk melukai atau menakuti orang atau membuat orang tertekan, trauma/depresi dan tidak berdaya.

\footnotetext{
${ }^{8}$ Allen, Kathleen, Journal, Classroom Management, Bullying and Teacher Practices, Spring, University of Rochester, 2010.

${ }^{9}$ Hertinjung, Jurnal, Profil Keperibadian 16 PF Pelaku dan korban bullying Fakultas Psikologi Universitas Muhammadiyah Surakarta, 2009

${ }^{10}$ Rigby, K, Bullying in school and the Mental Health of Child. Austalian Journal, 2005.
} 
Faktor yang mempengaruhi munculnya perilaku bullying pada siswa salah satunya adalah pola asuh permisif, pola asuh yang diterapkan orang tua kepada anaknya dapat memberi makna yang ambigu. Salah satu faktor yang mempengaruhi perilaku bullying adalah sebagai berikut, Faktor keluarga, Pola asuh keluarga , Orang tua yang menerapkan pola asuh permisif dan otoriter.

Bahwa faktor yang mempengaruhi perilaku bullying di sekolah adalah iklim sekolah, kebijakan sekolah dan pengawasan siswa memberikan kontribusi terhadap frekuensi terjadinya masalah perilaku bullying di sekolah di setiap sekolah tertentu.

Bentuk-bentuk perilaku bullying sebagai berikut: Verbal, Relational, Physical, Cyberbullying Dari uraian di atas dapat disimpulkan bahwa bentuk-bentuk perilaku bullying adalah: verbal, relational, physical, cyberbullying, fisik dan non fisik, bentuk isyarat, bentuk berkelompok.

\section{PENGERTIAN POLA ASUH PERMISIF}

Pola asuh permisif yaitu pola asuh yang di dalamnya ada kehangatan dan toleran terhadap anak, orang tua tidak memberikan batasan, tidak menuntut, tidak terlalu mengontrol dan cenderung kurang komunikasi.

Pola asuh permisif adalah sebuah keluarga yang tidak memiliki aturan yang kuat dan tidak konsisten, seperti ada ketegasan, namun beberapa waktu memperlihatkan perasaan dan emosi yang sehat padahal tidak konsisten diterapkan.

Pola asuh permisif adalah orang tua yang menghargai ekspresi diri dan pengaturan diri, hanya membuat sedikit batasan dan membiarkan anak memonitor aktivitas sendiri, namun orang tua tetap bersikap hangat, tidak mengontrol, dan tidak menuntut anak.

Pola asuh permisif tidak memiliki konsekuensi, peraturan dan hukuman bagi anak atas perbuatannya serta pola komunikasi yang terjadi hanya satu arah saja yaitu dari anak karena orang tua hanya mengikuti saja.

Berdasarkan pemaparan definisi pola asuh permisif diatas dapat disimpulkan bahwa pola asuh permisif adalah pola asuh yang diberikan keluarga kepada anaknya yang di dalamnya ada kehangatan dan toleran terhadap anak, yang mana orang tua tidak memberikan batasan terhadap anak untuk melakukan sesuatu, tidak menuntut, tidak terlalu mengontrol dan cenderung kurang komunikasi.

\footnotetext{
${ }^{11}$ Hurlock, E. B, Psikologi Perkembangan : Suatu Pendekatan SepanjangRentang Kehidupan, Jakarta : Erlangga, 2003.

${ }_{12}$ Hurlock, Psikologi Perkembangan :Suatu pendekatan Sepanjang Rentang Kehidupan, Jakarta : Erlangga, 2004.

${ }^{13}$ Coloroso, The Bully, Bulled and The Bystander. New York, 2006.
} 
Jenis-jenis pola asuh permisif menjadi dua sebagai berikut:

1) Pola asuh permisif indifferent (tidak peduli) Pola asuh permisif tidak peduli adalah suatu pola di mana orang tua sangat tidak ikut campur dalam kehidupan anak.

2) Pola asuh indulgen (memanjakan) Pada pola ini merupakan pola pengasuhan dimana orang tua sangat terlibat dalam kehidupan anak-anak mereka tetapi menetapkan sedikit batasan atau kendali terhadap mereka.

Lima karateristik utama dari pola asuh permisif yaitu:

1) Hadiah dan hukuman diberikan tidak konsisten.

2) Tanggung jawab yang tidak konsisten, penerapan hukuman yang inkonsisten diberikan pada anak.

3) Ancaman dan penyuapan, bentuk tindakan orang tua digunakan untuk mengontrol perilaku anak.

4) Perilaku didominasi oleh emosi, orang tua dan anak bertindak tanpa memikirkan konsekuensi yang akan muncul.

5) Cinta memiliki banyak syarat, guna mendapatkan kasih sayang oleh orang tua, anak harus menyenangkan orang tua.

\section{Pengertian Iklim Sekolah}

Secara konseptual iklim lingkungan atau suasana di sekolah didefinisikan sebagai seperangkat atribut yang memberi warna atau karakter, spirit, etos, suasana batin disetiap sekolah, secara operasional sebagaimana halnya defenisi iklim sekolah dapat dilihat dari faktor seperti kurikulum, sarana, dan kepemimpinan kepala sekolah dan lingkungan pembelajaran di kelas.

Iklim sekolah dimana pemberdayaan guru menjadi prioritas adalah sangat esensial bagi keefektipan sekolah yang pada muaranya mempengaruhi prestasi siswa secara keseluruhan. Iklim sekolah merupakan kultur atau sistem kenyakinan dan tata tertib di mana tugas-tugas dilaksanakan dengan kata lain iklim sekolah mempengaruhi tata cara bagaimana kita mengerjakan segala hal di sekolah. Lingkungan yang sehat disuatu sekolah memberikan kontribusi yang signifikan terhadap proses kegiatan belajar mengajar yang efektif. Iklim sekolah mempengaruhi dalam proses pembelajaran di sekolah dipandang sebagai salah satu faktor penentu keefektipan suatu sekolah. Peningkatan mutu iklim lingkungan sekolah mempengaruhi mutu lingkungan guru sehingga memberikan proses pembelajaran yang baik.

\footnotetext{
${ }^{14}$ Santrock, J.W, Andolescence. (11 ${ }^{\text {thn }}$ ed). New York:McGraw-Hill, 2007.

${ }^{15}$ Coloroso, The Bully, Bulled and The Bystander. New York, 2006.
} 
Berdasarkan penjelasan dari beberapa pendapat diatas. Dapat disimpulkan bahwa iklim sekolah merupakan suatu kondisidimana keadaan sekolah dan lingkungannya dalam keadaan yang sangat aman, nyaman dan damai dan menyenangkan untuk bekerja, belajar, bergaul dalam organisasi sekolah. Dengan kata lain iklim sekolah mempengaruhi tata cara bagaimana kita mengerjakan segala hal di sekolah. Dan mengajarkan anak untuk bisa berprilaku baik kepada orang-orang disekelilingnya, lingkungan yang sehat disuatu sekolah memberikan kontribusi yang signifikan terhadap perilaku yang positif dan meningkatkan perilaku anak menjadi baik

\section{Iklim Sekolah Yang Kondusif}

Iklim sekolah yang kondusif diharapkan terciptanya suasana yang aman, nyaman dan tertib, sehingga proses pembelajaran dapat berlangsung dengan tenang dan menyenangkan. Dimana iklim yang kondusif dalam suatu sekolah itu adalah sebagai berikut:Lingkungan yang aman, nyaman dan tertib, Ditunjang oleh optimisme dan harapan warga sekolah, Kesehatan sekolah, Kegiatan-kegiatan yang berpusat pada perkembangan peserta didik seperti halnya iklim fisik, suasana kerja yang tenang dan menyenangkan.

Dari uraian diatas maka dapat disimpulkan bahawa suatu iklim sekolah yang kondusif baik fisik maupun non-fisik merupakan landasanbagi pembentukan perilaku yang positif bagi peserta didik. Dan dimensi yang akan dijadikan indikator untuk meneliti iklim sekolahmeliputi dimensi hubungan, dimensi perkembangan pribadi dan pertumbuhan, dimensi perubahan dan perbaikan system, dimensi lingkungan fisik.

\section{Cara Mengkreasikan Iklim Sekolah}

Iklim sekolah itu tidak muncul dengan sendirinya, perlu diciptakan dan dibina agar dapat bertahan lama, untuk menciptakan iklim sekolah yang sehat dan produktif harus ada kesempatan dan kemauan para profesional untuk.

1) Saling memberi informasi, ide, persepsi dan wawasan.

2) Kerja sama dalam kelompok mereka.

3) Menciptakkan jaringan komunikasi yang memajukan ketergantungan para anggota satu dengan yang lain

4) Usahakan kegiatan-kegiatan yang dilakukan menyerupai hidup dalam keluarga dan hilanghkan situasi tegang.

5) Kalau ada permasalahan, berilah kesempatan orang atau kelompok yang paling bertalian dengan masalah itu menyelesaikan terlebih dahulu. Kalau mereka tidak bisa mengatasi baru dipecahkan bersama-sama. 
6) Wujudkan tindakan dalam setiap kegiatan yang menggambarkan bahwa lembaga pendidikan adalah milik setiap warga.

7) Mengusahakan agar fungsi kepemimpinan dapat dilakukan secara bergantian, sehingga tiap orang mendapat kesempatan mengalami sebagai pemimpin untuk menunjukkan kemampuannya.

8) Perlu diciptakan situasi-situasi yang membutuhkan pengambilan keputusan yang membuat para anggota tertarik pada kegiatan-kegiatan pengambilan keputusan untuk kepentingan bersama.

Dari uraian diatas maka dapat disimpulkan bahawa usaha-usaha untuk mengkreasikan iklim sekolah yang hangat dimulai oleh kepala sekolah atau para manajer lembaga pendidikan. Usaha-usaha tersebut juga perlu didukung oleh seluruh warga sekolah agar iklim sekolah yang hangat dapat tercapai dengan baik.

\section{Aspek- Aspek Iklim Sekolah}

Aspek iklim sekolah atas tiga aspek:

1) School policy against violence that include clear, consist and fair rules Kejelasan peraturan sekolah terhadap perilaku kekerasan, kejelasan ini terjadi secara konsisten dan peraturan yang adil. Meliputi pertimbangan para siswa mengenai kebijakan sekolah atau prosedur yang mengarah pada pengurangan kekerasan.

2) Teacher support of students

Dukungan yang diberikan guru terhadap siswa meliputi hubungan guru dan siswa yang dapat mendukung siswa.

3) Students participation in decision making and in the design of interventions to prevent school violence.

Sejauh mana keterlibatan siswa dalam pembuatan keputusan dan rancangan intervensi untuk pencegahan kekerasan di sekolah. Hal ini dapat dilihat dengan mengukur perasaan responden bagaimana peran siswa dalam melihat isu kekerasan di sekolah.

Dari uraian diatas maka dapat disimpulkan bahawa aspek-aspek dalam iklim sekolah adalah kejelasan peraturan sekolah terhadap perilaku kekerasan. Dukungan yang diberikan guru terhadap siswa meliputi hubungan guru dan siswa yang dapat mendukung siswa. Sejauh mana keterlibatan siswa dalam pembuatan keputusan dan rancangan intervensi untuk pencegahan kekerasan di sekolah.

\footnotetext{
${ }^{16}$ Walgito, B, Bimbingan \& Konseling disekolah. Edisi Ketiga, Yogyakarta: Andi Offiset, 1995.

${ }^{17}$ Lianawati, N. D, Pengaruh perilaku bullying dan iklim sekolah dengan pola asuh permisif terhadap siswa Negeri 5 Semarang”. Universitas Negeri Semarang, 2009.

${ }^{18}$ Gie, L. T, Cara belajar yang efesien. Jilid 1 Edisi Ke 5. Yogyakarta : PUB IB (Pusat Belajar Ilmu Berguna), 2002.
} 


\section{LAPORAN PENELITIAN}

Penelitian ini dilaksanakan pada MTs Al-Halim Sipogu. Kecamatan Batang natal Kabupaten Mandailing Natal Desa Sipogu. MTs Al-Halim Sipogu adalah kawasan yang secara umum merupakan lingkungan sekolah yang sejuk dan jauh dari keramaian kota,MTs Al-Halim Sipogu berdiri pada tahun 2013. Dinaungi oleh kementerian agama. kepala MTs Al-Halim Sipogu adalah ibu Rianti Siregar, S.Pd.I. Madrasah yang dipimpinnya memiliki guru sebagai tenaga pendidik dengan tingkat pendidikan S1 sederajat yang terdiri dari 15. Sekolah ini memiliki 6 Ruangan.

Untuk mendukung proses belajar mengajar dan kegiatan-kegiatan lainnya yang berkaitan dengan pelajaran dan pengembangan bakat pada siswa MTs Al-Halim Sipogu dilengkapi dengan fasilitas berupa gedung utama sebagai tempat proses belajar mengajar, ruang tata usaha, ruang kepala sekolah, ruang guru, ruang perpustakaan, ruang BP, ruang UKS, ruang koperasi, ruang bendahara, ruang sekretaris, kantin sekolah, masjid, laboratorium, lapangan tempat upacara, dan lapangan olah raga. Kegiatan ekstrakulikuler yang dikembangkan di sekolah ini antara lain, hafiz al-Qur'an, Pembiasaan ibadah wajib dan sunnah, bahasa arab, bola volley, tennis meja, dan bulu tangkis. Peneliti melihat bahwa fasilitas-fasilitas yang disediakan oleh pihak sekolah diterima dan digunakan oleh para siswa-siswi,seperti mesjid yang digunakan untuk melakukan ibadah dan pada waktu pelajaran olahraga guruselalu mengarahkan untuk mempergunakan semua fasilitas olahraga yang disediakan disekolah tersebut. Peneliti ini melibatkan siswa. MTs Al-Halim Sipogu. sebagai sampel peneliti yang berjumlah 72 siswa.

\section{Hasil Uji Reliabelitas}

Tabel 1.1

Reliabel Penelitian

\begin{tabular}{|l|c|c|}
\hline \multicolumn{1}{|c|}{ Variabel } & $\mathbf{r}_{\mathbf{1 1}}$ & Interprestasi \\
\hline Perilaku bullying & 0.925 & Reliabel \\
\hline Pola asuh permisif & 0.948 & Reliabel \\
\hline Iklim sekolah & 0.939 & Reliabel \\
\hline
\end{tabular}

2. Kategorisasi Data Penelitian

Tabel 1.2

Deskripsi Ketegorisasi Perilaku Bullying

\begin{tabular}{|c|c|c|c|c|c|}
\hline \multirow{2}{*}{ Variabel } & $\begin{array}{c}\text { Jumlah } \\
\text { Siswa }\end{array}$ & Persentase & \multirow{2}{*}{ Kategori } & $\begin{array}{c}\text { Jumlah } \\
\text { Siswa }\end{array}$ & Persentase \\
\cline { 5 - 6 } \cline { 5 - 6 } & \multirow{2}{*}{ (Orang) } & $(\%)$ & & $($ Orang) & $(\%)$ \\
\hline \multirow{2}{*}{40} & \multirow{2}{*}{100} & Tinggi & 22 & 55 \\
\cline { 5 - 6 } & & & Sedang & 13 & 32,5 \\
\cline { 5 - 6 } & & & Rendah & 5 & 12,5 \\
\hline
\end{tabular}


Tabel 1.3

Deskripsi Ketegorisasi Iklim Sekolah

\begin{tabular}{|c|c|c|c|c|c|}
\hline \multirow{2}{*}{ Variabel } & \multirow{2}{*}{$\begin{array}{c}\text { Jumlah } \\
\text { Siswa }\end{array}$} & \multirow{2}{*}{ Persentase } & \multirow{2}{*}{ Kategori } & $\begin{array}{c}\text { Jumlah } \\
\text { Siswa }\end{array}$ & Persentase \\
\cline { 2 - 6 } & $($ Orang) & $(\%)$ & & $($ Orang $)$ & $(\%)$ \\
\hline \multirow{2}{*}{$\begin{array}{c}\text { Iklim } \\
\text { Sekolah }\end{array}$} & \multirow{2}{*}{40} & \multirow{2}{*}{100} & Tinggi & 28 & 70 \\
\cline { 5 - 6 } & & & Sedang & 9 & 22,5 \\
\cline { 5 - 6 } & & Rendah & 3 & 7,5 \\
\hline
\end{tabular}

Tabel 1.4

Deskripsi Ketegorisasi Pola Asuh Permisif

\begin{tabular}{|c|c|c|c|c|c|}
\hline \multirow{2}{*}{ Variabel } & $\begin{array}{c}\text { Jumlah } \\
\text { Siswa }\end{array}$ & Persentase & \multirow{2}{*}{ Kategori } & $\begin{array}{c}\text { Jumlah } \\
\text { Siswa }\end{array}$ & Persentase \\
\cline { 2 - 3 } \cline { 5 - 6 } & $($ Orang) & $(\%)$ & & $($ Orang) & $(\%)$ \\
\hline \multirow{2}{*}{$\begin{array}{c}\text { Pola } \\
\text { asuh } \\
\text { Permisif }\end{array}$} & 40 & \multirow{2}{*}{100} & Tinggi & 11 & 27,5 \\
\cline { 5 - 6 } & & & Sedang & 28 & 70 \\
\cline { 5 - 6 } & & Rendah & 1 & 2,5 \\
\hline
\end{tabular}

Tabel 1.5

Uji Linieritas

\begin{tabular}{|l|l|c|c|l|}
\hline \multicolumn{1}{|c|}{ Variabel } & \multicolumn{1}{c|}{ P } & Sig & F & Ket \\
\hline $\begin{array}{l}\text { Perilaku bullying* } \\
\text { pola asuh permisif }\end{array}$ & $\begin{array}{l}\text { P }> \\
0.05\end{array}$ & 0.004 & 13.600 & Linear \\
\hline $\begin{array}{l}\text { Perilaku bullying * } \\
\text { iklim sekolah }\end{array}$ & $\begin{array}{l}\text { P }> \\
0.05\end{array}$ & 0,000 & 32.284 & Linier \\
\hline
\end{tabular}

Tabel 1.6

Hasil Uji Korelasi Pola Asuh Permisif Dengan Perilaku Bullying

\begin{tabular}{|l|c|c|}
\hline \multicolumn{1}{|c|}{ Variabel } & $\begin{array}{c}\text { Koef } \\
\text { Korelasi }\end{array}$ & Sig \\
\hline $\begin{array}{l}\text { Perilaku bullying } \\
\text { *pola asuh permisif. }\end{array}$ & $-0,393$ & 0,012 \\
\hline $\begin{array}{l}\text { Perilaku bullying * } \\
\text { iklim sekolah }\end{array}$ & $-0,639$ & 0,000 \\
\hline
\end{tabular}

Tabel 1.7

Analisis Regresi Sederhana Perilaku Bullying Dengan Pola Asuh Permisif

\begin{tabular}{|l|c|c|c|c|}
\hline \multicolumn{1}{|c|}{ Variabel } & R & $\mathbf{R}^{2}$ & Sig & BE\% \\
\hline $\begin{array}{l}\text { Perilaku bullying* pola asuh } \\
\text { permisif. }\end{array}$ & 0,393 & 0,115 & 0,012 & $1,15 \%$ \\
\hline
\end{tabular}


Tabel 1.8

Analisis Regresi Sederhana Hubungan Iklim sekolah Dengan

Perilaku Bullying

\begin{tabular}{|l|c|c|c|c|}
\hline \multicolumn{1}{|c|}{ Variabel } & R & $\boldsymbol{R}^{2}$ & P & BE\% \\
\hline $\begin{array}{l}\text { Perilaku bullying *iklim } \\
\text { sekolah. }\end{array}$ & 0,639 & 0,409 & 0,000 & 40,9 \\
\hline
\end{tabular}

Tabel 1.9

Analisis Regresi Berganda Hubungan PolaAsuh Permisif dan Variabel Iklim Sekolah Dengan Perilaku Bullying

\begin{tabular}{|c|c|c|c|c|}
\hline Variabel & R & $\mathbf{R}^{\mathbf{2}}$ & Sig & BE\% \\
\hline $\begin{array}{l}\text { Pola asuh permisif dan iklim } \\
\text { sekolah *perilaku bullying }\end{array}$ & 0,645 & 0,416 & 0,007 & 41,6 \\
\hline
\end{tabular}

\section{E. HASIL PENELITIAN}

Dari besarnya bilangan standar deviasi tersebut maka untuk variabel perilaku bullying apabila mean hipotetik < mean empiric dimana selisih melebihi bilangan satu standar deviasi, maka dinyatakan bahwa perilaku bullying tergolong tinggi dan apabila mean hipotetik > mean empiric dimana selisihnya melebihi bilangan satu standar deviasi maka dinyatakan bahwa perilaku bullying rendah.

Selanjutnya untuk variabel pola asuh permisif apabila mean hipotetik < mean empirik, dimana selisih melebihi bilangan satu standar deviasi maka dinyatakan bahwa pola asuh permisif tergolong tinggi dan apabila mean hipotetik > mean empirik dimana selisihnya melebihi bilangan satu standar deviasi maka dinyatakan bahwa pola asuh permisif rendah.

Selanjutnya untuk variabel iklim sekolah apabila mean hipotetik <mean empirik, dimana selisih melebihi bilangan satu standar deviasi, maka dinyatakan bahwa iklim sekolah tergolong tinggi dan apabila mean hipotetik > mean empirik, dimana selisihnya melebihi bilangan satu standar deviasi maka dinyatakan bahwa iklim sekolah rendah. Pada tabel dapat dilihat perbandingan mean hipotetik dengan mean empirik. Dapat dilihat pada tabel 4.15

Tabel 4.15

Perbandingan Mean Hipotetik dan Mean Empirik

\begin{tabular}{|l|c|c|c|c|c|}
\hline \multirow{2}{*}{ Variabel } & \multicolumn{2}{|c|}{ SD } & \multicolumn{2}{c|}{ Mean } & \multirow{2}{*}{ Ket } \\
\cline { 2 - 5 } & Hipotetik & Empirik & Hipotetik & Empirik & \\
\hline Perilaku bullying & 19 & 17,374 & 95 & 108,80 & \multirow{2}{*}{ Tinggi } \\
\hline Pola asuh & 18,5 & 25,019 & 92,5 & 124,53 & \multirow{2}{*}{ Tinggi } \\
\hline
\end{tabular}




\begin{tabular}{|l|c|c|c|c|c|}
\hline permisif & & & & & \\
\hline Iklim sekolah & 19,5 & 23,832 & 97,5 & 106,75 & Tinggi \\
\hline
\end{tabular}

Penelitian ini bertujuan untuk mengetahui ada hubungan Pola asuh permisif dan iklim sekolah dengan perilaku bullying pada siswa MTs Al-Halim Sipogu. Hasil koefisien determinasi berdasarkan dari hasil analisis data sebesar -0,693. Hal ini menunjukkanbahwa variabel pola asuh permisif dan iklim sekolah dengan perilaku bullying. Uji signifikan diperoleh nilai 0,000.

Ini berarti sig $<0,05$. Pengujian signifikansi bertujuan untuk mengetahui signifikansi variabel pola asuh permisif dan iklim sekolah memiliki kontribusi terhadap perilaku bullying. Analisis data yang diuji adalah terdapat hubungan pola asuh permisif dan iklim sekolah dengan perilaku bullying.

Hasil koefisien determinasi berdasarkan dari hasil analisis data sebesar-0,393. Hal ini menunjukkan bahwa variabel pola asuh permisif dengan perilaku bullying. Uji signifikan diperoleh nilai 0,012 . Ini berarti sig $<0,05$.

Pengujian signifikansi bertujuan untuk mengetahui signifikansi variabel pola asuh permisif memiliki kontribusi terhadap perilaku bullying. Analisis data yang diuji adalah terdapat hubungan pola asuh permisif dengan perilaku bullying.

Hasil koefisien determinasi berdasarkan dari hasil analisis data sebesar 0,501. Halini menunjukkan bahwa variabel iklim sekolah dengan perilaku bullying. Uji signifikan diperoleh nilai 0,000 . Ini berarti sig $<0,05$. Pengujian signifikansi bertujuan untuk mengetahui signifikansi variabel iklim sekolah memiliki kontribusi terhadap perilaku bullying. Analisis data yang diuji adalah terdapat hubungan iklim sekolah dengan perilaku bullying.

Menurut Sejiwa (2008) menjelaskan bahwa perilaku bullying adalah sebuah situasi dimana terjadinya penyalaguna kekuatan/kekuasaan yang dilakukakn oleh seseorang/kelompok. Pihak yang kuat di sini tidak hanya berarti kuat dalam ukuran fisik tetapi bisa juga kuat secara mental.

Pada hasil penelitian hubungan pola asuh permisifdengan perilaku bullying dimana koefisien determinasi berdasarkan hasil analisis data sebesar 0,393. Hal ini menunjukkan bahwa 
variabel pola asuh permisif terhadap perilaku bullying yaitu sebesar 15,5\% dengan signifikan 0,012 sedangkan sisanya dipengaruhi oleh variabel lain.

Pada hasil penelitian hubungan iklim sekolah dengan perilaku bullying dimana koefisien determinasi berdasarkan hasil analisis data sebesar 0,639. Hal ini menunjukkan bahwa variabel iklim sekolah berkontribusi perilaku bullying yaitu sebesar 40,9\% sedangkan sisanya dipengaruhi oleh variabel lain.

Pengujian signifikansi bertujuan untuk mengetahui signifikansi iklim sekolah terhadap perilaku bullying. Analisis data yang diuji adalah terdapat hubungan antara iklim sekolah dengan perilaku bullying. Uji signifikan diperoleh nilai 0,000. Ini berarti sig $<0,05$. Hal ini menunjukan bahwa iklim sekolah mempengaruhi perilaku bullying. Artinya, hipotesis terbukti kebenarannya.

Pada hasil penelitian pengaruh iklim sekolah dengan perilaku bullying dimana koefisien determinasi berdasarkan hasil analisis data sebesar 0,645. Halini menunjukkan bahwa variabel iklim sekolah berkontribusi perilaku bullying yaitu sebesar $41,6 \%$ sedangkan sisanya jadi pengaruhi oleh variabel lain. Pengujian signifikansi bertujuan untuk mengetahui signifikansi iklim sekolah terhadap perilaku bullying. Analisis data yang diuji adalah terdapat hubungan antara iklim sekolah dengan perilaku bullying. Uji signifikan diperoleh nilai 0,000. Ini berarti sig $<$ 0,05. Hal ini menunjukan bahwa iklim sekolah mempengaruhi perilaku bullying. Artinya, hipotesis terbukti kebenarannya.

Bahwa pola asuh permisif adalah sebuah keluarga yang tidak memiliki aturan yang kuat dan tidak konsisten, seperti ada ketegasan, namun beberapa waktu memperlihatkan perasaan dan emosi yang sehat padahal tidak konsisten diterapkan.

Bahwa iklim sekolah adalah sebuah sistem yang secara sadar menyelaraskan aktivitasaktivitas yang dilakukan oleh anggota-anggotanya dan mempengaruhi perilakunya. Sekolah adalah sebuah organisasi yang memiliki tujuan-tujuan objektif yang ingin dicapai dan untuk mencapai tujuan yang objektif tersebut diperlukan iklim sekolah yang baik. 
Dari data di atas diambil kesimpulan bahwa ada hubungan yang signifikan antara pola asuh permisif dan iklim sekolah dengan perilaku bullying pada siswa MTs Al-Halim Sipogu.

\section{F. PENUTUP}

Berdasarkan hasil analisis regresi linear sederhana dan berganda dapat disimpulkan bahwa:

1. Ada hubungan antara pola asuh permisif dan iklim sekolah dengan perilaku bullying pada siswa MTs Al-Halim Sipogu. Dengan koefisien $R=0,645$ nilai $p=0,000$ berarti $(p<0,01)$ dengan kontribusi sebesar $4,6 \%$.

2. Ada hubungan antara pola asuh permisif dengan perilaku bullying pada siswa MTs Al-Halim Sipogu. Dengan koefisien $\mathrm{R}=0,393$ nilai $\mathrm{p}=0,001$ berarti $(\mathrm{p}<0,01)$ dengan kontribusi sebesar $15,5 \%$.

3. Ada hubungan antara iklim sekolah dengan perilaku bullying pada siswa MTs Al-Halim Sipogu. Dengan koefisien $\mathrm{R}=0,639$ nilai $\mathrm{p}=0,000$ berarti $(\mathrm{p}<0,01)$ dengan kontribusi sebesar 40,9 $\%$. 


\section{DAFTAR PUSTAKA}

Abu Darwis, Pengubahan Perilaku Menyimpang Murid Disekolah Dasar, Jakarta : Depdiknas, 2006.

Ahmad Baliyo Eko Prasetyo, Bullying disekolah dan dampaknya bagi masa depan anak, Jurnal Pendidikan Islam : Vol.4. No, 2011.

Allen, Kathleen, Journal, Classroom Management, Bullying and Teacher Practices, Spring, University of Rochester, 2010.

Coloroso, The Bully, Bulled and The Bystander. New York, 2006.

Dariyo, A \& Ling, Y, Interaksi Sosial Di Sekolah dan iklim sekolah menengah umum (SMU). Phronesis, 2002.

Rigby, K, Bullying in school and the Mental Health of Child. Austalian Journal, 2005.

Hurlock, E. B, Psikologi Perkembangan : Suatu Pendekatan SepanjangRentang Kehidupan, Jakarta : Erlangga, 2003.

Hurlock, Psikologi Perkembangan :Suatu pendekatan Sepanjang Rentang Kehidupan, Jakarta : Erlangga, 2004.

Lianawati, N. D, Pengaruh perilaku bullying dan iklim sekolah dengan pola asuh permisif terhadap siswa Negeri 5 Semarang”. Universitas Negeri Semarang, 2009.

Gie, L. T, Cara belajar yang efesien. Jilid 1 Edisi Ke 5. Yogyakarta : PUBIB (Pusat Belajar Ilmu Berguna), 2002.

Hertinjung, Jurnal, Profil Keperibadian 16 PF Pelaku dan korban bullying Fakultas Psikologi Universitas Muhammadiyah Surakarta, 2009.

Sejiwa, Kekerasan terhadap anak makin memiriskan, Mei, 5, 2016. http://sejiwa.org/kekerasanterhadap-anak-makin-memiriskan/, 2008.

Sejiwa foundation, Penelitian mengenai kekerasan di sekolah, Jakarta:Grasindo, 2010.

Santrock, J.W, Andolescence. (11 ${ }^{\text {thn }}$ ed). New York:McGraw-Hill, 2007.

Olweus, D, Bullying : Fact and intervention. Norwegia: Research Center for Health Promotion, University Of Bergen, 2006.

Walgito, B, Bimbingan \& Konseling disekolah. Edisi Ketiga, Yogyakarta: Andi Offiset, 1995. 